\title{
TOWARDS TEXT DIDACTISATION FOR THE PURPOSE OF DEVELOPING TRANSLATION SKILLS
}

\author{
Katarina Seresova \\ University of Economics in Bratislava, Slovak Republic \\ katarina.seresova@euba.sk \\ Daniela Brevenikova \\ University of Economics in Bratislava, Slovak Republic \\ daniela.brevenikova@euba.sk
}

\begin{abstract}
The authors deal with one of the key issues in teaching translation, namely selecting suitable texts for in-class translation training. Translation belongs to the core courses in the study programme "Foreign Languages and Intercultural Communication" at the Faculty of Applied Languages, University of Economics in Bratislava. For the text to be selected for the purpose of its didactisation, and in this way to contribute to the development of translation skills, it has to fulfil numerous criteria. The focus of this paper is on text topic and its content, text type, text length, and degree of text complexity. Learners need to be prepared for diverse situations; therefore they have to be exposed to diverse text types in terms of topic and genres. As far as the criterion of text length is concerned, we consider shorter texts more suitable for training translation, because they enable teachers to work with several texts within one lesson unit and study texts on various topics. We deal with the text complexity in terms of content, as well as syntactic structures and lexical density. Text complexity has to be adapted to learners' language, professional and cultural level of students. Features of this kind of text and criteria of text selection described in the paper are based on domestic and international sources as well as on authors' experience in teaching translation and their own translation activities.
\end{abstract}

Keywords: translation skills; translation studies; translation textbook; text selection; text type; text length; text complexity; translation training.

\section{Introduction}

In recent decades, but in particular after Slovakia's admission to the European Union, translation studies as the science of translation and interpretation started to rise in importance as an accompanying phenomenon of approximation of the Union's countries in economy, politics, culture and social sciences. Translation contributes to facilitating the communication between two or more partners, each of whom speaks only their mother tongue. This is one of the key reasons why the course in translation and interpretation occupies an important place in the academic curricula at the Faculty of Applied Languages, University of Economics in Bratislava and belongs to the core courses in the study programme in "Foreign Languages and Intercultural Communication" offered by this institution. The mission of the Faculty of Applied Language (FAL) University of Economics in Bratislava is to provide a high-standard education, which includes communicative competence in two foreign languages (in combinations: English - German / French, Spanish; German / French or Spanish), intercultural communication, translation and interpreting, fundamentals of economics, law and selected social sciences. Principle objectives of the courses in translation include the capability of working with the source language (English/German/French, etc.) and the target language (Foreign language or Slovak) by means of text analysis and to adequate transform texts into the target language (Slovak or a foreign language); highlight the role of context in translation, as well as acquire the fundamentals of translating various genres and text registers. Main outcomes from the translation course are: mastering of text typology in practice, symbiosis of the content and form, including grammatical forms and stylistic varieties, and an adequate (correct) translation of texts on area studies. These courses are offered both at Bachelor's and Master's levels (Bachelor: three terms, 78 (in-class) hours; Master: three terms, 78 hours). Education of translators under the study programme mentioned focuses in particular on their general education, basic knowledge in the field, text analysis competences, translation strategies, as well as a good command of relevant terminology in business and economics, social sciences, and law (Seresova, 2010; 2014).

The aim of the paper is (1) to outline main trends in the development of textbooks for translation purposes; (2) to create a background for the selection of a suitable textbook for the interdisciplinary academic environment.

Features of this kind of text and criteria of text selection described in the paper are based on domestic and international Slovak sources as well as on authors' experience in teaching translation and their own translation activities. The focus of this paper is on the criteria of selecting a suitable text in terms of text topic and content, text type, text length, and degree of text complexity. 


\section{Characteristic Features of Text Suitable for Teaching Translation Studies}

One of the competences of a teacher of translation is the ability to select relevant course materials for developing translation competences.

It may appear at first sight that selecting a text to be translated in a language class and its didactisation is a quite an easy task. However, when looking at the problem closer, we find out that the task is really demanding, and it has a crucial role in the success or failure of the instruction in translation skills. For this reason, the topic of the paper belongs to the aspects that have to be considered when selecting texts to be used as source materials in a translation course at a higher education institution.

In our opinion, there are few suitable textbooks in the book market that can be used as the basic learning source for learning and teaching translation skills. Many course materials currently at disposal often become obsolete even before they are published. Moreover, most translation textbooks focus on theoretical aspects of translation studies rather than providing practical ideas on how to efficiently train translation skills (Seresova, 2014). In addition, there are several textbooks that focus on developing various translation strategies, which can be used as the main course material in the process of building and developing translation skills. These include, for instance, Nord (1990), Hoenig and Kussmaul (1982), Hammer and Henschelmann (1983), Newmark (1998), and others. There are some more recent publications which are used in translation education at Slovak universities in accordance with the needs of socio-economic practice; they include textbooks of languages for specific purposes and manuals for translators and interpreters (Ehrgangova \&Keniz, 1999; Hrehovcik, 2006; Hrehovcik \& Bazlik, 2014; Kvetko, 2015; Seresova, 2010).

However, very often teachers themselves select relevant source materials and their subsequent didactisation for translation training purposes. For this reason, we would like to reflect in this paper on what sorts of text are suitable for designing translation tasks. Hönig and Kußmaul (1991) claim that teachers are inclined to choose for this purpose the texts that are interesting and witty and that deal with cultural, historical, sociological, and philosophical topics; all of these are the types of texts that translators encounter in their professional practice. This state-of-the-art probably results from the opinion that translating is a boring activity, and as such, this activity has to be made more interesting and pleasant for future translators by means of offering them stimulating and highly topical texts. This opinion indicates that the process of building and developing translation skills starts from a careful text selection, which is based on the consideration of characteristic features of a text.

Teachers' opinions on the selection of texts suitable for teaching translation vary. Some recommend working with the texts that are both interesting and entertaining, thinking they cannot ask their students to translate a "boring" delivery note or an instruction how to operate a complex machine, which nobody knows" (Kautz, 2002). Others (e.g. Raksanyiova, 2009; Gromova, 2012) believe that few translators are able to predict the kind of texts they will translate in the future; for this reason, learners should obtain practice in all text types. And there is still another group of authors who claim that the best approach is if learners are exposed to texts that contain the broadest possible spectrum of language means and structures so that they acquire a wide range of translation skills. Consequently, an ideal solution from this point-of-view is fiction texts or texts used in everyday life. The last variant is to select the texts that the teachers themselves feel competent to teach and master them in terms of content and form (compare also: Belenkova \& Davtyan, 2016).

\section{Criteria for Text Selection}

In many countries (Germany, France, Britain, etc.) discussions have been conducted by teachers of translation studies on the criteria of text selection in teaching translation studies, the starting point of which was the C. Nord's publication on "Textanalyse und Uebersetzen" (1995). The following list of recommendations is based on the ideas of numerous authors (e.g. Belenkova \& Davtyan, 2016; Janulevičiene \& Kavaliauskiene, 2015; Keniz, 2010; Sánchez-Gijón, 2009; Seresova, 2009; Trujillo, 2016; Tuharska, 2015).

The text is suitable for didactisation if:

- it provides ample quantity of starting points for mediating and strengthening skills in the course of analysis of the source text, or in creating the target text; it means that the text is suitable for the purpose if it contributes to improving the learner's translation competence.

- the process of strengthening the learner's translation competence is accompanied by the development of knowledge of one's mother tongue and a foreign language, as well as that of intercultural concepts;

- the text can be included in the system of mutually related exercises for teaching translation skills;

- it is an authentic text, i.e. the text has to be applicable in translation practice;

- the source was written in the author's mother tongue, i.e. it is free of spelling and other mistakes;

- it is a sample of some text type, for instance, a commercial order should include typical elements of this type of text, while very informal written documents should not be used for this purpose; 
- the text contains the source from which it is derived and it is available in its original version;

- the text is relevant to the target recipient, i.e. the recipient has to be able to understand its content and related context; the text background needs to be clear. Therefore, the types of text as the satire or commentaries on hot news within one country are not suitable for teaching translation as they cannot be understood by foreigners. For this reason, mainly texts on technology, economy, law, and natural sciences are most frequently used for translation instruction (Kautz, 2002; Hrehovcik \& Bazlik, 2014 );

- the text is a follow up to or is connected with the translator's later specialisation.

We beg to differ with this final criterion as few students of translation studies are able to determine in advance in which particular field they are going to be professionally active; consequently, we do not consider this criterion to be relevant for text selection. Nowadays, translators have to be multi-professionals ready to cope with developments in the application of corpora (Levicka, 2014) or the education in audiovisual translation (Zelonka, 2012, pp.99-126), as well as technical documentation or editing tasks; they need to able to process new terminology, as well as working in translator teams or manage translation projects (Gromova, 2012, p. 12). Raksanyiova (2009) emphasises the need for flexibility in the education of future translators in this respect, and sees this as a way of coping with the challenge posed to translators in the $21^{\text {st }}$ century. Foreign authors, for example, emphasise the need for taking into consideration the changes in the framework of the European Higher Education Area (EHEA) (Sánchez-Gijón et al, 2009). In this context, we can state that the current book market in Slovakia reflects a rising need for translating texts for specific purposes (Hrehovcik \& Bazlik, 2014).

\section{Text Type}

Trujillo (2016) considers the kind of text "an organizational system for the teacher" and her text taxonomy contains four macro-genres, namely 1) information documents; 2) official and administrative documents; 3) transport and accompanying documents; and 4) financial documents (Trujillo, 2016, p. 7). Kautz (2002) describes three types of text in his work: the first type is the information text, which is used most frequently in teaching translation. Informative texts deal with technology, economy, law, etc., and they come in the various forms, for instance contracts, agreements, laws, but also advertisements, offers, and the like.

Another text type, which serves as a starting point for translation training, is the expressive text, which includes also fiction, personal diaries, or biographies. This text type is used less frequently as a source text in translation training and is recommended mainly for advanced courses.

The third text type, which is also less frequently applied for developing translation skills, is the operative text. The function of operative texts is to persuade rather than provide information, for instance, a poster, billboard, out-of-home advertisement, etc.

Dvorecky (1998) points to the lack of uniform approach to classification of text types and citing Gopfering, he refers to her classification of text types based on the text communicative function, containing the following four types of text: legal normative texts, updating texts (oriented to technological progress), instructive - didactic texts, and texts of the compression function (Dvorecky, 2011, p. 180).

The Slovak linguist Kvetko (2009) deals with text types in the section on text-restricted translation studies and differentiates between non-literary and literary types of text. The former group includes technical/scientific texts, institutional texts, and general information texts; the latter includes from fiction and poetic texts. Kvetko's publication "An Introduction to Translation Studies" designed for teaching a practical course in translation contains useful samples of these text types and tasks for the analysis and interpretation focused on the comprehension of differences between various text types, identification and description of methods of translation and specific features of specific text types, and, in the case of literary texts, comparison of the source text and the target text (Kvetko, 2015, pp. 132-159).

In our opinion, while considering also our students' comments about the most suitable text type for our translation courses, we can state that learners need to be are prepared for diverse situations. As our students can hardly be sure about the type of organisation they will be employed, they need to be exposed to all types of text.

\section{Text Length}

The text designed for the analysis and translation by learners in the course of acquiring translation skills has to meet an important condition, namely, an adequate length. It means its size should enable learners to process and submit the task assigned by the teacher. Based on our teaching experience, we can state that the aim of teaching translation is not to translate the longest possible text within the time limit. On the contrary, the aim is that learners may utilise the text in the most effective way, so that they could learn from it as much as possible and were able to solve specific problems arising from the text that is being translated. Moreover, 
learners need to be able to use in practice the methods and strategies, which they have already mastered. From the didactic aspect, in particular, shorter texts are more suitable for training translation, because they enable the teacher to work with several texts within one lesson unit and study texts on various topics, or those that which involve various translation-related problems. Useful ideas related to an optimum text length for training translation can be drawn from Trujillo's comments about the short form and long form of documents used in translation courses (Trujillo, 2016, p.8).

\section{Degree of Text Complexity}

The text that the teacher uses as a background for translation exercise has to meet some criteria related to text difficulty or complexity. The issue on the degree of text complexity as a criterion of selecting a suitable material for training translation has been frequently discussed in international educational documents (Pisa, 2007, p. 28; as cited in Trujillo, 2016) and research in translation (Trujillo, 2016, p.7). Firstly, the text complexity in terms of topic and content has to be adapted to learners' language, professional and cultural level of students. It means that for the learners who are beginners in this area the teacher selects an easier text in terms of content with clear syntactic constructions, with current means of expression, the best solution from this aspect could be the text in an everyday general language and related to the everyday communication situation. By contrast, students who have been studying translation for a longer time and have already acquired basic translation skills and strategies, could be asked to translate texts from various fields, containing complicated syntactic constructions, terminology, and the like. Naturally, even translators - beginners may have to cope with a more difficult text: however, it is necessary that the teacher clarifies possible linguistic or extra-linguistic associative meaning (of which the learner may not be aware). Learners should have relevant dictionaries at disposal and need to be explained specific grammatical phenomena in the text, so that they were able to work with the selected text without major difficulties; a difficult text, for example in terms of lexical density and syntactic constructions, is likely to result in learners' demotivation.

Texts submitted for translation by the teacher have to fulfil certain formal criteria, for instance, they need to be legible and written on an acceptable level (Kvetko, 2015). A student has to have at their disposal an ample time for working out the translation, i.e. the learner cannot be asked to work under pressure of time, since the quality of translation considerably declines under the circumstances. They need to have at disposal suitable technical means and text processing facilities (Levicka, 2014). In the case of vague expressions, which need to be clarified in consultations, we recommend giving priority to students' team working, which will, ultimately, significantly contribute to increasing translation competences of all the learners involved.

\section{Conclusion}

The choice of the right text for in-class translation is an important part of a teacher's preparation for a course in translation. A good decision in this area significantly affects the success or failure of a course in translation studies. However, it is not just the teacher's success or failure that matters: here, the success depends on the quantity and quality of new knowledge and skills, which the learners can acquire in the process of creating the target text in the course of text analysis and translation. If the teacher selects a text that is unsuitable in any way, the student cannot learn how to apply the acquired translation approaches, methods and strategies in practice. Consequently, the selected text would not fulfil the basic criteria of suitability for the learning and teaching translation skills. For this reason, teachers should adhere to the criteria listed in the paper, so that they could be satisfied not only with their learners' achievements, but also with their own teaching performance. As future translators, our learners should be informed about current developments in the translation market; the textbooks they use in translation courses need to reflect the new roles of translators as multi-professionals.

\section{Acknowledgement}

The present paper is one of the partial outputs from the research project No. 029EU-4/2016 "Academic and Scientific Language in University Environment", funded by the Committee of the Educational Grant Agency (KEGA), Ministry of Education, Research and Science and Sports, Slovak Republic.

\section{References:}

Ehrgangova, E. \& Keniz, A. (1999). Kapitoly z prekladu a tlmocenia [Chapters in translation and interpreting]. Bratislava, Publishing House Ekonom.

Belenkova, N. \& Davtyan, V. (2016). Correlation of translation and other language activities. International Journal of Environmental and Science Education, 11 (18), 10951-10959.

Brevenikova, D. (2008). Miesto prekladu vo vyucbe odbornej cudzojazycnej komunikacie [Role of translation in teaching professional communication in foreign languages]. In Od textu k prekladu III (pp. 27-31). Praha: Jednota tlumocniku a prekladatelu. 
Dvorecky, M. (2011). Typologia textov v kontexte prekladu odbornych textovych zanrov archeologie [Text typology in the context of professional text genres of archeology]. In D. Zvoncekova (Ed.), Letná škola prekladu 10. Preklad ako tvorba a autorská činnost' (pp.173-186). Bratislava: Slovak Professional (Non-literary) Translators' Society.

Gromova, E. (2012). Preklad a tlmočenie v europskom kulturnom priestore (nove vyzvy a perspektivy) [Translation and interpreting in the European cultural area (New challenges and prospects)]. In D. Zvoncekova (Ed.), Letna skola prekladu 11. Kriticky stav prekladu na Slovensku? Modus vivendi a modus operandi v európskom kulturnom priestore, 34 (pp. 7-17). Bratislava: Slovak Literary Translators' Society.

Hoenig, H. \& Kussmaul, P. (1982). Strategie der Uebersetzung [Strategy of translation]. Tübingen: Narr.

Hammer, F. \& Henschelmann, K. (1983). De la grammaire à la traduction: Einführung in die deutsch-französische Übersetzung. [On grammar of translation: Introduction to German - French translation]. Muenchen: Hueber.

Hrehovcik, T. (2006). Prekladatelske minimum [Translator minimum]. Bratislava: Iris.

Hrehovcik, T. \& Bazlik, M. (2014). Sudny preklad a tlmočenie [Certified translation and interpreting]. Bratislava: Wolters Kluwers.

Janulevičiene, V.V. \& Kavaliauskiene, G. G. (2015). ESP students' self-evaluation and attitude towards translation. Journal of Language and Literature, 6(2), 38-43.

Kautz, U. (2002). Handbuch Didaktik des Uebersetzens und Dolmetschens [Handbook of Didactics of Translation and interpreting]. Muenchen: IUDICIUM Verlag.

Keniz, A. (2010). Tvorivý aspekt v umeleckom a kazdom inom preklade [Creative aspect in literary translation as well as in any other translation]. In D. Zvoncekova (Ed.), Letna skola prekladu 9. Odborny a umelecky preklad v Europskej unii, 32 (pp.39-50). Bratislava: Slovak Professional (Non-literary) Translators' Society

Kvetko, P. (2015). Translation Studies. An introductory coursework (Fourth edition). Trnava: St. Constantine and Methodius University in Trnava.

Levicka, J. (2014). Korpus ako zdroj terminologickych informacii relevantnych pre preklad. [Corpus as a source of terminology information relevant for translation]. In D. Zvoncekova (Ed.), Letna skola prekladu 13. Čas a priestor v prekladatelskej praxi, 36 (pp. 86-94). Bratislava: Slovak Professional (Non-literary) Translators' Society.

Newmark, P. (1998). A Textbook of Translation. Shanghai Foreign Language Education Press.

Nord, C. (1990). Uebersetzen lernen - leicht gemacht [Learn to translate - the easy way]. Heidelberg: Gross.

Nord, C. (1995). Textanalyse und Übersetzen [Text analysis and translation]. Heidelberg: Gross.

Raksanyiova, J. (2009). Translation Studies at Comenius University in Bratislava: Facts and Figures. Materialy/Matters. World Literature Studies, 4. 1 (18), 63-67. Retrieved March, 15, 2017 from http://www.wls.sav.sk/wp-content/uploads/WLS_4_09/raksanyiova.pdf

Sánchez-Gijón, P., Aguilar-Amat, A., Mesa-Lao, B., \& Solé, M.P. (2009). Applying terminology knowledge to translation: Problembased learning for a degree in translation and interpreting. Terminology, 15(1), 105-118.

Seresova, K. (2009). Translatologie in der Praxis (Wirtschaftsdeutsch) [Translation studies in practice (Business German)]. Bratislava: Publishing House Ekonom.

Seresova, K. (2010). Nemecky odborny text ako predmet prekladu [German professional text as the subject of translation]. Bratislava: Publishing House Ekonom.

Seresova, K. (2014). Moderna ucebnica prekladu odborneho jazyka hospodarstva, spolocenskych vied a prava [Modern textbook of the language of economy, social sciences and law ]. Project proposal No. 006EU-2014 submitted to the Committee of the Educational Grant Agency (KEGA), Ministry of Education, Research and Science and Sports, Slovak Republic.

Trujillo, K. S. (2016). La enseñanza de la traducción comercial (Inglés-Español): Una propuesta formativa [English Commercial Translation (English-Spanish): A Teaching Proposal]. Monografias de Traduccion e Interpretacion, 8, 257-278.

Tuharska, Z. (2015). Text als Medium der Informationsvermittlung. Eine Studie zur Textsorte "didaktisch angelegter fachsprachlicher Text" unter Berücksichtigung pragmasyntaktischer Ansätze [Text a medium of information transfer. A study on text-types "didactically suitable professional text" from the pragmatic-syntactic approaches]. In H. Bergerova, G. Schuppener, \& P. Szatmari (Eds.), Aussiger Beiträge. Germanistische Schriftenreihe aus Forschung und Lehre Text und Stil im Wandel - neue Perspektiven der Textlinguistik und Stilistik, 9 (pp. 229-252). New York: Springer Science + Business Media LLC..

Zelonka, J. (2012). Moznosti vzdelavania v oblasti audiovizualneho prekladu v zahranici a vyzvy pre slovenske akademicke prostredie [Options for education in the area of audiovisual translation available abroad and challenges for Slovak academic environment]. In D. Zvoncekova (Ed.), Letna skola prekladu 11. Kriticky stav prekladu na Slovensku? Modus vivendi a modus operandi v europskom kulturnom priestore, 34 (pp.99-126). Bratislava: Slovak Literary Translators' Society (SSPUL). 